\title{
Interactive comment on "Brief communication: Organochlorine pesticides in an archived firn core from Law Dome, East Antarctica” by M. Bigot et al.
}

\section{Anonymous Referee \#3}

Received and published: 25 August 2016

In order to understand better the magnitude and to limit the environment's damage, it is clearly necessary to know about transportation, accumulation and concentration changes of organic pollutants through ages. One irreplaceable source to obtain some of this information is the investigation of chemical compounds in polar ice cores. Since snowflakes have the capacity to adsorb gas-phase chemical compounds, ice-sheets represent an archive of notions of the varying deposition of trace chemicals. From the stratigraphy of the ice cores, the ice-sheets can be temporally related, and every core can cover the chemical history of many decades. Antarctica's low temperatures during the whole year both reduce the speed of chemical reactions and allow the ice layering two bulk samples from the upper sections from an "old" ice core from Law Dome for organochlorine pesticides: few studies have been published, so the paper is another 
small step towards knowledge about contaminants transport mechanism in the atmosphere. The ice core used in this study was drilled on Law Dome, a small ice cap with independent ice flow located on the edge of the main East Antarctic ice sheet (a map could be useful for many readers). The characteristics of Dome Summit South (DSS), include a high annual accumulation rate $(0.7 \mathrm{~m} / \mathrm{yr}$ ice equivalent), relatively low mean surface temperatures $\left(-21.8^{\circ} \mathrm{C}\right)$, and low wind speeds $(8.3 \mathrm{~m} / \mathrm{s})$. These site characteristics lead to highly resolved records with clear annual cycles in most measured parameters, giving very robust chronological control. I did not find any of this information on the paper, and I have to find myself, in the literature, despite their fundamental importance. As RC1 wrote, it is also absolutely important to have more information around storage/handling contamination, but not only, the sampling conditions must absolutely be considered and described: was it a manual drilling or not? I think not, the ice-drilling was too deep (1196 m), this "modus operandi" can have influenced the results. The relationship between Arctic and Antarctic pollutants concentration amount may be taken into consideration, but cannot become the key to any conclusions. While it may be true that no earlier firn core studies are available to use as a guide for sample volume needed from Antarctica for OCPs, I think the volume used is really too big, a tenth could be enough for a more defined (in time) measurement.

P3L19: C. E.?

I recommend that the paper is accepted after these comments are considered.

Interactive comment on The Cryosphere Discuss., doi:10.5194/tc-2016-178, 2016. 